DOI: $10.19195 / 0137-1150.167 .22$

\title{
ELENA BORISOVA-YURKOVSKAYA
}

Uniwersytet Warszawski, Polska

\section{Смерть как событие повседневности в творчестве Алексея Ремизова и Василия Розанова}

\section{Смерть и повседневность в жизнетворческом мифе}

Алексей Ремизов и Василий Розанов — фигуры для русского модернизма знаковые, каждый из них самобытен и неповторим, однако творческий диалог писателей, не прервавшийся даже после смерти Розанова, дает возможность взглянуть с перспективы более широкого культурного контекста на общие для обоих писателей темы. Одна из них, бесспорно, тема смерти. Интенсивное и напряженное внимание к проблеме смерти, особый, неклассический взгляд на традиционно определенные в христианском дискурсе границы между жизнью и смертью, новаторская стилистика текстов о смерти и загробной жизни характерны для творчества обоих авторов.

Розанов - философ, литературный критик, автор работ о Льве Толстом и Федоре Достоевском, яркий публицист с особым художественным стилем - сам не написал ни одного собственно литературного произведения, и тем не менее его творчество - неотъемлемая часть литературного процесса конца XIX-начала XX веков. Виктор Шкловский в эссе, посвященном анализу творческого метода Розанова, доказывает принципиальную литературность таких его книг, как Опавшие листья (1915) или Уединенное (1912). Сырой и, на первый взгляд, необработанный материал газетных вырезок, случайных наблюдений и заметок вместе с исповедальным тоном, по мнению Шкловского, необходимы Розанову, чтобы утвердить новый жанр и ввести в литературу темы, которые давно ждали своего певца: быт, кухня, семья ${ }^{1}$. Так вопреки господствовавшему декадентскому панэстетизму соз-

${ }^{1}$ В. Б. Шкловский, Розанов, [в:] его же, Гамбургский счет: Статьи - воспоминанияэссе (1914-1933), Москва 1990, с. 101-115. 
дается художественно-философский коллаж из папирос, бани и приходнорасходной книги.

В Ремизове, мастере бытового анекдота и мифотворце повседневности, Розанов нашел искреннего и близкого по духу друга. Личная дружба и общее идейное поле стали почвой для формирования особого жизнетворческого супертекста с характерной для эстетики Серебряного века тенденцией к размыванию границ между искусством и жизнью. Они писали друг о друге много и охотно, неизменно выдерживая тональность гротескной повседневности как в бытовых зарисовках, так и во взаимных характеристиках. Ремизов в мемуарной книге Иверень (1986) пишет, что „Розанова занимало только человеческое, - «вещи пустые, мизерные, слов нестоящие», «беспрерывная мелочь событий жизни», - «семейный вопрос»"2. Именно из такой „мелочи событий жизни” собрана мозаика одной из самых новаторских книг Ремизова. Синтетическая в жанровом отношении Кукха. Розановы письма (1923) написана после смерти Розанова и не только, как понятно из заглавия, ему посвящена, но, прежде всего, наследует стилистику Розановых Onавиих листьев. Эта книга без сюжета, основана на воспоминаниях и письмах. Она поразила современников - как когда-то и книги Розанова - интимностью тем, переходящих границы приличия ${ }^{3}$.

Ремизова, как нам кажется, критиковали не столько за выбор тем, сколько за неуместность фамильярного тона по отношению к умершему. Обращаться с памятью о покойном подобным образом - значит открыто войти в конфликт с христианской традицией. Хотя критики Ремизова вряд ли могут быть названы ортодоксальными христианами, но и у них житейское правило „о покойниках либо хорошо, либо никак”, сработало рефлекторно.

И вместе с тем, Кукха как раз благодаря кухонно-бытовой стилистике, образам, позаимствованным у Розанова, а главное лейтмотиву книги смерти - глубоко лирична. Кукха - это продолжение диалога с умершим другом так, как он сам завещал. Ремизов обращается к мертвому как к живому, без принятой по отношению к покойникам почтительной дистанции, без несвойственной при жизни Розанову серьезности. Ремизов рассказывает $m y \partial a$, в вечность, о своей трудной доле эмигранта, о литературных новостях, спрашивает друга, как ему теперь там живется:

А знаете, Василий Васильевич, как нынче хорошо писать стали молодые [...]. А как это хорошо, что так и остались вы в России. И я знаю, представься вам случай нет, вы никогда бы не покинули Россию [...]. Мы, Василий Васильевич, бесправные тут [...]. А что, Василий Васильевич, теперь вы поняли, что никакой папироски там

2 А. М. Ремизов, Иверень, [в:] его же, Собрание сочинений, т. 8, Москва 2000, с. 503.

${ }^{3}$ О негативной реакции, например, 3. Гиппиус и Ю. Айхенвальда, см.: Е. Р. Обатнина, Алексей Ремизов: Личность и творческие практики писателя, Москва 2008, примечания № 282 и № 802. 
и не надо? [...] Ну как пробуждение - и ничего подобного нашему: и то, да не то, где самое „хочу” по-другому и разное по месту жительства в вечности. А как там насчет сроков в этой вашей — что слышно в вечности?

Та же рядоположенность жизни и смерти видна в текстах Розанова. Разговор о смерти не предполагает смены интонации, не содержит и намеков на сакральную глубину темы. Напротив, смерть описана как событие банальное в своей повседневности. В одном пассаже Уединенного Розанов описывает картину своих похорон: лужи на дороге, он в гробу „с глуповатым лицом", скучающие друзья, одному из которых очень хочется курить, но никак нельзя - событие слишком торжественное. И Розанов-покойник сочувствует товарищу: „[...] я из гроба ужасно ему сочувствую, что нельзя «закурить», и не будь бы отпет и вообще такой официальный момент, когда я «обязан лежать», то подсунул бы ему потихоньку папироску"5.

Официальность дискурса смерти разрушается Розановым и на следующих страницах книги:

Несите, несите, братцы: что делать - помер. [...] Не трясите очень. Впрочем, не смущайтесь, если и тряхнете. Всю жизнь трясло. [...] Покойник в гробу должен быть „руки по швам”. Я всю жизнь ,руки по швам” (черт знает перед кем). Закапывайте, пожалуйста, поскорее и убирайтесь к черту с вашей официальностью. Непременно в земле скомкаю саван и колено выставлю вперед. Скажут: „Иди на страшный суд”. Я скажу: „Не пойду”. - „Страшно?” — „Ничего не страшно, а просто не хочу идти. Я хочу курить. Дайте адского уголька зажечь папироску”. — „У вас Стамболи?”-— „Стамболи”. — „Здесь больше употребляют Асмолова. Национальное”б.

Посмотрим внимательнее с помощью каких художественных приемов достигается эффект десакрализации смерти. В жизни трясло (в переносном смысле), умер — трясет (в прямом смысле); всю жизнь руки по швам (в переносном смысле), и в гробу — руки по швам (в прямом смысле). Происходит редукция глубины высказывания. Смерть не загадочнее, а, наоборот, прямее, линейнее жизни. И, наконец, уравнивание этого и того света завершается в фантастическо-реалистическом диалоге с чертом о папиросах: разница между мирами заключается только в предпочтениях относительно марки сигарет.

Ремизов также неизменно подчеркивал проходимость границ, конструировал литературные ситуации зазора между мирами. Тут можно вспомнить сатирические некрологи, которые Ремизов посвящал живым друзьям перед их отъездом из Вологды, где те отбывали ссылку ${ }^{7}$. В своей „бытовой автобиографии”, как характеризует Учителя музыки (1981) Ремизов, писатель приводит рассказ о том, как к прислуге Акулине приходил по ночам

\footnotetext{
${ }^{4}$ А. М. Ремизов, Кукха, [в:] его же, Собрание сочинений, т. 7, Москва 2002, с. 72-142.

5 В. В. Розанов, Уединенное, [в:] его же, Сочинения, т. 2, Москва 1990, с. 270.

6 Там же, с. 272.

7 Подробнее о шуточных некрологах и их роли в жизнетворческом мифе Ремизова см.:
} Е. Обатнина, Алексей Ремизов: Личность и творческие практики писателя, Москва 2008. 
покойный зять и вел с ней беседы, одну из которых подслушали хозяин и его гости. Умерший обсуждал со своей родственницей вещи что ни на есть повседневные: „Вот туфли-то плохие положила она ему в гроб, сносил он... - стало быть, - делает вывод повествователь, - не в каретах там разъезжают, а может, и холод такой же и беда такая же?"8 Акулина просит зятя привезти ей говядины, а на прощанье живая с мертвым „словно бы поцеловались: что-то чмокнуло". Умерший остается частью жизни, с ним не только можно вести беседы, но, например, целоваться или обмениваться реальными предметами: ему - туфли, он - говядину. Опыт контакта с мертвым наводит на мысль о рядоположенности миров: там всё то же самое, тот же холод, та же нищета.

Но особенно заметно внимание Ремизова к теме повседневности смерти в литературных произведениях, выполненных в фольклорной стилистике. С одной стороны, писатель в изображении ликов смерти идет за богатой традицией древнерусских сказок, сказаний и легенд, с другой стороны, можно отметить своего рода намеренное коллекционирование мертвецов живое с мертвым сталкиваются каждый раз по-разному, но, заметим, неизменно в горизонтальной плоскости. На страницах его книг появляется целый сонм существ из того мира или из пограничья между мирами, то ли полуживых, то ли полумертвых. Вот мертвый лапландский колдун „нойда", которого смельчак везет хоронить на кладбище. Колдун умер, но ночью ожил. Возница вступает с ним в бытовой диалог, сначала увещевает мертвеца, затем переходит к угрозам и обещает его зарезать:

Оглянулся - а мертвец сидит. „Коли помер, лежи!” - крикнул на мертвеца. Послушал мертвец, лег. Поехали дальше. Глухая ночь. И опять испугались олени: мертвый сидел в гробу. Тогда выскочил из саней возница, выхватил из-за пояса нож: „Ложись! — кричит. — Коли не ляжешь, зарежу!",10

В сказке Мертвеи из цикла Докука и балагурье (1914) веселая затея подвыпивших на празднике крестьянских парней - выкопать свежего покойника и попугать односельчан - оборачивается для них трагедией. Ведут двое мертвого под руки, третий ноги ему переставляет, в какой-то момент покойник сам пошел. Третий успевает смекнуть, что мертвый ожил, и убегает, а двух других покойник уже крепко держит. Плач и мольбы парням не помогли, через два дня - делать нечего — „повели их на кладбище с мертвецом закапывать. И так и закопали равно вместе - того мертвеца не живого, а этих живых"11. У читателя остается чувство абсурда от прочитанного,

8 А. М. Ремизов, Учитель музыки: Каторжная идиллия, [в:] его же, Собрание сочинений, т. 9, Москва 2002, с. 41.

9 Там же.

10 Там же, с. 20.

11 А. М. Ремизов, Учитель музыки: Каторжная идиллия, [в:] его же, Собрание сочинений, т. 9, Москва 2002, с. 288. 
странной бессмыслицы происходящего; на первый план выходит не страх или сочувствие героям, но ощущение онтологического дискомфорта. Мертвое настолько далеко продвинулось в мир живого, что удалить его можно, только вырвав вместе с частью живого. В пространстве ремизовской сказки не действуют христианские законы: мертвецы оживают, а „Господь не прощает"12.

\section{Холод смерти против домашнего тепла}

Попробуем разобраться в причинах, по которым происходит деконструкция классического дискурса о смерти в текстах обоих авторов, постараемся ответить на вопрос, почему смерть вводится в круг жизни. Для этого обратимся к статьям и эпистолярному наследию Розанова. Философ Розанов в отличие от писателя Ремизова, чаще давал комментарии по поводу тех или иных вопросов, изложенных в его работах, вступал в публичные споры о религии, отстаивал и аргументировал свою позицию. Мы сделаем два приближения к розановскому дискурсу о смерти: обратимся к его спору с философами Дмитрием Мережковским и Павлом Флоренским, которые выступали против Розанова в вопросе понимания смерти и перспектив загробной жизни, хотя и стояли на разных позициях по отношению друг к другу.

Розанов на протяжении нескольких лет публикует три статьи, посвященные смерти. На статью Вечная тема (1908) следует резкий ругательный отклик Мережковского. Позиция Розанова: интересно здесь, а там - неинтересно; „я согласен, пусть не будет рая, но пусть останется все, как есть”"13 возмутила Мережковского. Властитель умов начала века обрушивается на приятеля со статьей Мистические хулиганы (1908), обвиняя его в мистическом анархизме:

„Уничтожив Бога, разрушим все, что есть”, - говорит андреевский Савва. „Уничтожив Бога, оставим все как есть”, - говорит Розанов. Но и здесь, как везде, крайности сходятся: абсолютное мещанское „принятие мира” без Бога и абсолютное хулиганское „неприятие мира” тоже без Бога ведут, в последнем счете, к одному и тому же - к отказу от всякого действия, к успокоению в мещанском быте или в хулиганском небытии, к последнему безразличию, смешению добра и зла, красоты и безобразия, Бога и дьявола в одном хаосе, в одной слякоти ${ }^{14}$.

Отказ от рая во имя вечной повседневности кажется Мережковскому покушением на метафизические основы мира, на возможность различать противоположности, на его коренной дуализм, который подвергнуть сомнению тогда еще казалось невозможным. У Розанова были веские причи-

12 Там же.

13 В. В. Розанов, Вечная тема, „Новое время” № 11427, 1908, с. 3.

14 Д. С. Мережковский, Мистические хулиганы, [в:] его же, Избранное, Кишинев 1989, c. 457. 
ны вернуть „свой билет на вход”"15, отказаться, подобно Ивану Карамазову, от гармонии.

В 1910 году в альманахе с характерным для вкусов эпохи fin de siècle названием Смерть появляется статья Розанова Смерть... и что за нею, где он подробно излагает причины своего бунта против смерти и отказа от христианского взгляда на вечную жизнь. Он пишет:

Смерть есть холод, врывающийся в теплоту жизни. Это как вышибленное в стужу зимою окно: вдруг понесло снегом, задул ветер, загасил свечу. Смерть - ужас, безобразие, разлом. Смерть - катастрофа. Всякая. Для всякого ${ }^{16}$.

Смерть - зло, которое приходит разрушить жизнь, а точнее, конкретную частную жизнь. Бессмысленно и жестоко она кладет конец тому главному, чем живет и чем так дорожит человек, - его семье. Смерть - холод и разрыв. Жизнь - тепло дома, единение с семьей. Смерть вырывает человека из тепла, уюта и любви, поэтому главное отношение к смерти - ужас. Из отвлеченной пары категорий в эссеистике Розанова жизнь и смерть превращаются в конкретные, личные жизнь и смерть, со всеми их обстоятельствами и значением, которое они имеют для близких людей.

У Ремизова мы встречаем то же отношение к смерти. Он искренне жалеет умершего Александра Блока, говорит, что „это такое проклятье”, „такая беда":

Бедный Александр Александрович! покинуть так рано землю, никогда уж не видеть ни весен, ни лета, ни милой осени и любимых белоснежных зим - и звезд не видеть сестер манящих — как только они нам светят! Не видеть земли, без „музыки” — это такая последняя беда, и от этой беды не уйти $[\ldots]^{17}$.

Мысль о смерти, известия о печальной судьбе, постигшей знакомых и близких людей, порождают острое чувство бессмысленности жизни. Если все равно каждая, любая жизнь кончится одинаково, то зачем жить, зачем к чему-то стремиться, каков тогда смысл этого мира. Розанов и в $У e-$ диненном, и в Oпавщих листьях в ужасе повторяет одну и ту же не дающую покоя мысль: „Могила [...] знаете ли вы, что смысл ее победит целую цивилизацию [...] И эти два слова: «зарыт человек», «человек умер», своим потрясающим смыслом, своим великим смыслом, [...] преодолевают всю планету $[. . .]^{\prime 18}$; и:

15 Ср. спозицией Ивана Карамазова, изложенной в главе Бунт: „Да и слишком дорого оценили гармонию, не по карману нашему вовсе столько платить за вход. А потому свой билет на вход спешу возвратить обратно" (Ф. М. Достоевский, Братья Карамазовы, Москва 2000, c. 252).

16 В. В. Розанов, Смерть... и что за нею, [в:] Альманах Смерть, Санкт-Петербург 1910, c. 257.

17 А. М. Ремизов, Взвихренная Русь, [в:] его же, Собрание сочинений, т. 5, Москва 2000, c. 380 .

18 В. В. Розанов, Уединенное..., с. 270. 
Да, „смерть” одолевает даже математику. „Дважды два — ноль”. Мне 56 лет: и помноженные на ежегодный труд дают ноль. Нет, больше: помноженные на любовь, на надежду дают ноль. Кому этот „ноль” нужен? Неужели Богу? Но тогда кому же? Зачем? [...] Ужасные вопросы. Смерти я боюсь, смерти я не хочу, смерти я ужасаюсь ${ }^{19}$.

А если со смертью заканчивается не только жизнь, но происходит утрата всех ее смыслов, значит загробной жизни и обещанной справедливости не существует. По крайней мере, в это невозможно верить. Розанов относится в той (довольно многочисленной) генерации религиозных мыслителей, для которых вера становится глубоко проблематична.

Смерть заставляет сменить обычную для жизни перспективу, она делит даже взгляд на привычные вещи на до и после нее. Розанов выступает против смены перспективы, против обычаев, которые сакрализируют смерть. Это его ответ на холодящий ужас неизбежного конца: во что бы то ни стало остаться по эту сторону, сохранить за собой право и там быть, как тут. В одной из своих „хулиганских”, по выражению Мережковского, статей 20 Розанов рассуждает о странном обычае снимать с покойника нательные кресты и образки из драгоценных металлов, надевая взамен простой двухкопеечный кипарисовый крестик. Он выходит к религиозно настроенной (часто не ортодоксально) читательской аудитории „Весов” с категорическим отказом менять золотой крест, который получил от жены, и серебряный образок, который когда-то положил на глаза своей умиравшей дочери Надюши, на деревянный символ смиренного отказа от земных сокровищ. Он отказывается расставаться с дорогими сердцу вещами, заявляет, что все, что он любит здесь, желает сохранить и там. Этот проникновенный, очень убедительный пассаж об умирающей дочке и далеко идущие выводы о снятии границ между мирами, об отказе признавать другую перспективу как более ценную, истинную, единственно значимую, обнажает истоки нехристианской мировоззренческой позиции Розанова. Мережковский, находясь в споре с историческим христианством, не случайно почувствовал серьезную угрозу метафизической религиозности как таковой, исходящей не от традиционных противников представлений о воздаянии в виде адских мук или атеистов, отрицающих существование Бога, но от Розанова, утверждающего, что Бог есть, но провозглашаюшего, что там неинтересно, нечего там делать.

Платон и греческие мудрецы учили искусству умирания, считая его истинной сущностью философии. Смерть Сократа и изложенные им на смертном одре доказательства бессмертия души, о чем мы узнаем благодаря Платону из диалога Федр, один из символических камней в фундаменте классической парадигмы метафизической реабилитации смерти.

19 В. В. Розанов, Опавшие листья. Короб первыци, [в:] его же, Сочинения, т. 2, Москва 1990, c. 278.

20 В. В. Розанов, Мечта в щзелку, „Весы” 1905, № 7. 
Позднее христианство будет учить о загробной жизни („смертию смерть поправ”), напоминая об опасности второй смерти („смертию умрешь”). Смерть, таким образом, имеет ценность только в перспективе загробной жизни бессмертной души. Смерть - необходимые врата в вечную жизнь, высшая точка человеческой жизни. Для Розанова и Ремизова классическая метафизика с ее жесткой вертикальной структурой неубедительна, для них смерть не высшая точка, но злое событие. Так же снимается вопрос о смысле смерти - она просто бессмысленна.

Розанов пишет, что с утверждением христианства изменяется перспектива; языческое наслаждение радостями жизни уступает аскетической культурной доминанте: „с рождением Христа, с воссиянием Евангелия все плоды земные вдруг стали горьки. Во Христе прогорк мир, и именно от Его сладости $[\ldots]$..21. Для Розанова метафизический пафос христианства теряет свою привлекательность; философ-модернист то открыто восстает против догматов христианства, то, формально не отказываясь от христианского дискурса, разламывает его изнутри: „...жизнь есть дом. А дом должен быть тепел, удобен и кругл. Работай над «круглым домом», и Бог тебя не оставит на небесах. Он не забудет птички, которая вьет гнездо [жирный шрифт В. Розанов]"22. Ценность переносится сверху вниз, с небес на землю. Это отказ от классической дуалистической аксиологии, от движения по вертикальной линии от одного полюса к другому.

Павел Флоренский верно замечает стремление Розанова освятить посюстороннее, боготворить и запечатлеть в вечности настоящее. Между философами разворачивается серьезная эпистолярная полемика о христианстве, семейном и половом вопросах, загробной жизни. Флоренский пишет Розанову:

Христианство же не любите, потому что оно требует самоотвержения, а Вы хуже огня боитесь всякой трагедии, всякого движения. Вы живете только настоящим. Вы хотите мыслить мир статически, перенося на него атрибут Вечности. Вы хотите боготворить мир. Христианство не дает Вам сделать этого, — вот Вы раздражены на христианство $[\ldots]^{23}$.

Бесконечная, неподвижная повседневность становится идеалом, защищающим от смерти, за которой нет ничего: только холод, пустота и обнуление достижений жизни. Отсюда и попытки приручить смерть, включая ее в пространство живого через практики жизни. На страницах текстов по-

${ }^{21}$ В. В. Розанов, В темных религиозных лучах. Темный лик, http://az.lib.ru/r/rozanow_w_w/text_1908_v_temnyh_luchah.shtml [дата обращения: 30.07.2017].

22 В. В. Розанов, Апокалипсис намего времени, [в:] его же, Собрание сочинений, т. 12, Москва 2000, с. 60.

23 П. Флоренский, Письмо В. Розанову от 21 декабря 1908 г., [в:] В. В. Розанов, Собрание сочинений. Литературные изгнанники. Книга вторая, Москва-Санкт-Петербург 2010, с. 13. 
являются существа, обживающие пограничье, способности, позволяющие поддерживать контакт с мертвыми, эпатаж и шутки по поводу смерти, снимающие острое чувство страха перед ней.

\section{Земной рай вечной повседневности}

В русской литературе есть пример повседневной идиллии, заключенной в вечность, гимн „круглому дому”. Думается, мы не ошибемся, если скажем, что как для Ремизова, так и для Розанова картина семейного счастья героев повести Николая Гоголя Старосветские помещики (1835) являет собой образ земного рая, противостоящего смерти и разрушению.

Философия семейной идиллии Розанова получила широкую известность, выше мы приводили фрагменты из его текстов, где он аргументирует свою позицию по данному вопросу. Эссе Райская тайна из цикла размышлений над текстами русской литературы Огонь вещей (1954) показывает, насколько близок Ремизов розановской домоцентристской повестке: не надо вечной жизни, оставьте все, как есть. Ремизов открыто выступает против ставшего к тому времени уже хрестоматийным мнения Виссариона Белинского. В пику критику, увидевшему в повести только привычку и пошлость, он говорит о силе любви:

В „Старосветских помещиках” дано в математически-чистом виде блаженное райское состояние человека, освобожденного от мысли и желаний, над которыми тяготеет первородное проклятие время-смерть, показать чтобы высшее и единственное: любовь человека к человеку ${ }^{24}$.

Мысли не посещают героев повести (ведь мысль - это примета поджидающей смерти), не мучат, не печалят их, а желания в земном раю, где всего в изобилии, ограничены до предела - „попить, поесть, поспать” 25 - исполняются мгновенно. Ремизов, как и Розанов, не боится обвинений в пошлости, не боится бытовых и кухонных тем, наоборот, он воспевает дом и в этом деле берет себе в союзники Гоголя. Вместо высокой культуры, утонченной философской мысли, желаний и стремлений двигаться вперед, он декларирует идеал, заключающийся в том, чтобы остаться на месте, „попить, поесть, поспать” и не о чем не думать. „В «Старосветских помещиках» представлен сказочный рай - сад, который Бог насадил для человека" 26 - пишет Ремизов. Условием существования рая на земле является любовь. Только любовь вечна, только она способна дать человеку рай на земле. Тому, кто, как говорил Розанов, ,работает над «круглым домом»", будет дано Господом, Он не оставит человека, заботящегося о своем гнезде.

24 А. М. Ремизов, Райская тайна, [в:] его же, Собрание сочинений, т. 7, Москва 2002, c. 140 .

25 Там же.

26 Там же, с. 139. 


\section{Библиография}

Достоевский Ф. М., Братья Карамазовы, Москва 2000.

Мережковский Д. С., Мистические хулиганы, [в:] его же, Избранное, Кишинев 1989.

Обатнина Е. Р. Алексей Ремизов: Личность и творческие практики писателя, Москва 2008.

Ремизов А. М., Взвихренная Русь, [в:] его же, Собрание сочинений, т. 5, Москва 2000.

Ремизов А. М., Иверень, [в:] его же, Собрание сочинений, т. 8, Москва 2000.

Ремизов А. М., Кукха, [в:] его же, Собрание сочинений, т. 7, Москва 2002.

Ремизов А. М., Мертвеи, [в:] его же, Собрание сочинений, т. 2, Москва 2000.

Ремизов А. М., Райская тайна, [в:] его же, Собрание сочинений, т. 7, Москва 2002.

Ремизов А. М., Учитель музыки: Каторжная идиллия, [в:] его же, Собрание сочинений, т. 9, Москва 2002.

Розанов В. В., Апокалипсис нашего времени, [в:] его же, Собрание сочинений, т. 12, Москва 2000

Розанов В. В., В темных религиозных лучах. Темный лик, http://az.lib.ru/r/rozanow_w_w/ text_1908_v_temnyh_luchah.shtml [дата обращения: 30. 07. 2017].

Розанов В. В., Вечная тема, „Новое время” 1908, № 11427.

Розанов В. В., Мечта в щелку, „Весы” 1905, № 7.

Розанов В. В., Опавщие листья. Короб первый, [в:] его же, Сочинения, т. 2, Москва 1990.

Розанов В. В., Смерть... и что за нею, [в:] Альманах Смерть, Санкт-Петербург 1910.

Розанов В. В., Уединенное, [в:] его же, Сочинения, т. 2, Москва 1990

Флоренский П., Письмо В. Розанову от 21 декабря 1908 г., [в:] В. В. Розанов, Собрание сочинений. Литературные изгнанники. Книга вторая, Москва-Санкт-Петербург 2010.

Шкловский В. Б., Розанов, [в:] его же, Гамбургский счет: Статьи - воспоминания - эссе (1914-1933), Москва 1990.

\section{Death as an everyday event in the works of Aleksey Remizov and Vasily Rozanov}

\section{Summary}

The paper addresses the topic of death in the works of Aleksey Remizov and Vasily Rozanov, the two iconic intellectuals of the early twentieth century in Russia. Based on the works of fiction, essays, articles and correspondence of two writers, study reveals and analyzes the similarities of their philosophical and aesthetics views. It shows how the phenomenon of death is depicted in everyday life and undergoes desacralization. It also includes polemic with the philosophical milieu of the epoch (D. Merezhkovsky, P. Florensky) and the literary tradition (on the example of N. Gogol).

Keywords: mysticism of everyday life, being, absurd, Russian philosophical thought, literature of the Silver Age 


\section{Śmierć jako wydarzenie codzienności w twórczości Aleksieja Remizowa i Wasilija Rozanowa}

\section{Streszczenie}

Artykuł przedstawia temat śmierci w pracach Aleksieja Remizowa i Wasilija Rozanowa dwóch ikonicznych intelektualistów początku XX wieku. Na materiale utworów literatury pięknej, esejów, artykułów i korespondencji pisarzy autor ujawnia i analizuje podobieństwa ich poglądów filozoficznych i estetycznych. Pokazuje przy tym, jak fenomen śmierci jest włączany do przestrzeni codzienności i ulega desakralizacji. Uwzględnia również polemikę ze środowiskiem filozoficznym epoki (Dymitr Mereżkowski, Paweł Florenski) i tradycję literacką (na przykładzie Nikolaja Gogola).

Słowa kluczowe: mistycyzm codzienności, byt, absurd, rosyjska myśl filozoficzna, literatura srebrnego wieku 